\title{
APPLICATION OF NUMERICAL AND EMPIRICAL MODELS FOR GROUNDWATER LEVEL FORECASTING
}

\author{
Devarajan $K^{1}$, Sindhu $\mathbf{G}^{2}$ \\ ${ }^{1}$ M.Tech Student, College of Engineering Trivandrum \\ ${ }^{2}$ Associate Professor, College of Engineering Trivandrum
}

\begin{abstract}
Groundwater flow modelling is necessary for sustainable management of groundwater resources. Numerical and empirical models can be effectively used for modelling of groundwater flow. The specific boundary conditions, hydrogeological variables and complex aquifer structures are the pre requisite for numerical models but empirical models entirely depends on the data available for input and output parameters. This paper aims to compare the effectiveness of the numerical model using MODFLOW and empirical model Radial Basis Function Neural Network (RBFNN) developed for forecasting the groundwater levels of Athiyannoor Block Panchayath of Trivandrum district, which is categorized as semi critical zone due to the rapid decline in groundwater level. The groundwater flow model was developed with weekly groundwater level data during January 2014 to December 2014. Model was calibrated using trial and error method and groundwater levels at 10 observation wells were simulated. Using the simulated model, groundwater levels were predicted and validated from January 2015 to March 2015. The inputs to the RBFNN model includes weekly groundwater recharge, evapotranspiration, pumping rate in the pumping wells and groundwater levels in these wells at the previous time step. The trained RBFNN model is then validated. The predicted groundwater levels by numerical model and RBFNN models were compared with the observed groundwater levels during the validation period. The performance characteristics of both models indicate that RBFNN model is better than numerical model using MODFLOW for weekly groundwater level forecasting.
\end{abstract}

Keywords: Groundwater level, MODFLOW, RBFNN, Numerical model, Empirical model

\section{INTRODUCTION}

Groundwater is one of the naturally available fresh water resources all around the world. Due to rapid increase in the population, urbanization and agriculture, demand for the fresh water increases. Groundwater is mostly preferred to meet these requirements since it is distributed in a larger area below the ground and has less contamination levels. The excessive pumping from existing groundwater resources without aid of much recharge which is called 'groundwater mining' had produced problems such as seawater intrusion in coastal aquifers and dry well formations in the inland areas. Such problems can be avoided by taking proper management strategies. This is achieved through groundwater flow modelling, which includes simulation and prediction of groundwater levels under various management scenarios. Then suitable draft operation policy or conjunctive water use policy is established for sustainable use of groundwater resources. Groundwater level forecasting is one of the major parts of such management models.

Empirical models and deterministic models are widely used for groundwater level forecasting. Empirical models are solely based on the data available and neural networks are the part of such models. Neural networks are widely employed in groundwater level forecasting due to the non linear characteristics of groundwater level and its influencing factors. Due to strong non linear mapping ability and flexible network structure, neural networks are highly fault tolerant compared to deterministic models (Chang et al., 2013).
Artificial Neural Network (ANN) with Back Propagation (BP) training and RBFNN are the important types of neural networks that are extensively used for groundwater level forecasting. Both the networks have different structure and learning algorithms. But RBFNN is simple, converges faster and have stable prediction results than ANN with BP training (Chang et al., 2013). Deterministic models estimates future groundwater levels using the groundwater flow equation in an aquifer system. Numeric models are popular among deterministic models in which entire study domain is considered. In the numeric models, area of interest is subdivided into cells and the basic groundwater flow equation is solved for each cell usually considering its water balance. The groundwater level at each cell is calculated using the solution of groundwater flow equation. The partial differential equation of groundwater flow for each cell is replaced by an algebraic equation which is solved numerically, through an iterative process thus called numeric models (Kresic., 1996). Finite difference based MODFLOW is an example for such models. In the present paper, a groundwater flow model was developed using numerical model MODFLOW and RBFNN. Using these models, groundwater levels were predicted, validated and compared. Athiyannoor block Panchayath of Trivandrum district is taken as the study area. 


\section{LITERATURE REVIEW}

Mohanty et al., (2013) conducted a study to forecast the groundwater levels using numerical model MODFLOW and Artificial Neural Network (ANN) for 18 observation wells of Mahanadi deltaic system, Eastern India. Comparison of results from both the models shows that ANN is good for short range groundwater level forecasting and MODFLOW is good for long range groundwater level forecasting.

Varalakshmi et al., (2012) developed a three dimensional groundwater flow model for the Osmansagar and Himayathsagar catchments, using visual MODFLOW software. They had carried out detailed geophysical studies and subsurface formations were identified and compared with borehole litho logs. Groundwater levels were predicted up to 2020 and a management strategy was developed to avoid groundwater depletion in that area.

Mohsen et al., (2010) had predicted and compared long and short duration groundwater levels using Support Vector Machines (SVM) and ANN for Towaco aquifer in the North Western part of Morris country. They concluded that weekly predictions are more accurate than daily predictions even though data availability is less. Also they had shown that SVM is good for longer range predictions and ANN is good for short range predictions.

Coppola et al., (2003) evaluated weekly groundwater level predictions of 12 monitoring wells in Florida, USA using MODFLOW and ANN under different pumping rates and climatic conditions. The predictions from ANN were much better than MODFLOW.

Xu Chang et al., (2013) compared the performance of BP and RBFNN for the simulation of groundwater levels in Mongolia. Simulation was performed for summer irrigation period as well as autumn irrigation period. Eventhough both the models had given reasonably accurate results, performance of RBFNN was much better than BP neural networks.

\section{METHODOLOGY}

The methodology consists of two sections viz. groundwater level forecasting using numerical model MODFLOW 2000 and RBFNN.

\subsection{Groundwater Level Forecasting using} MODFLOW

A numerical model is developed by MODFLOW software to analyse the temporal variation of groundwater level in an aquifer system. MODFLOW utilizes a numeric solution of the equation governing groundwater flow through porous media for mathematical computations and simulations as shown in equation (1).

$$
\frac{\partial}{\partial x}\left(K_{x x} \frac{\partial H}{\partial x}\right)+\frac{\partial}{\partial y}\left(K_{y y} \frac{\partial H}{\partial y}\right)+\frac{\partial}{\partial z}\left(K_{z z} \frac{\partial H}{\partial z}\right)-\underset{(\text { Eqn. 1) }}{\mathrm{W}}=S_{s} \frac{\partial H}{\partial t}
$$

Where $\mathrm{K}_{\mathrm{xx}}, \mathrm{K}_{\mathrm{yy}}, \mathrm{K}_{\mathrm{zz}}$ : hydraulic conductivity along the $\mathrm{x}, \mathrm{y}$ and $\mathrm{z}$ axes, $\mathrm{H}$ : hydraulic head, $\mathrm{W}$ : volumetric flux per unit volume and represents source or sink, $\mathrm{S}_{\mathrm{s}}$ : specific storage of porous material and $\mathrm{t}$ : time.

The concept development is the first step in the groundwater flow modelling. Then real physical boundaries of the study area need to be specified. If such boundaries don't exist, hydraulic boundaries have to be considered. Model grid is then generated in which study area is discretized in to cells or blocks. Then input parameters such as elevation, groundwater level, hydraulic conductivity (horizontal and vertical), specific storage, porosity, recharge, evapotranspiration, pumping rate and river stage have to be given. Then boundary conditions such as no flow boundaries and constant head boundaries need to be specified. After that initial conditions are specified, then model is made to run and calibration should be done by trial and error method. The calibration is completed when Normalised Root Mean Square Error becomes less than $10 \%$. Then model predictions can be carried out.

\subsection{Groundwater Level Forecasting using RBFNN}

The Radial Basis Function Neural Network is feed-forward in nature and consists of input layer, hidden layer or radial basis layer and an output layer or linear layer. The hidden layer consists of number of nodes and parameter vector called center, which applies nonlinear transformation to the input source. For each node, standard Euclidean distance is measured between center and input vector of network and is transformed by a nonlinear function which determines output of nodes in the hidden layer. The most common transformation is the Gaussian function as nonlinearity of the hidden nodes. The Gaussian function for a neuron has a center and a radius (called spread). Many neurons are required to fit fast changing function for large values of spread, whereas network will not be generalized for small values of spread. The output values of the network are computed as linear combination of the output of hidden nodes.

The output $y$ of RBFNN is determined using the equation (2).

$$
y=f(u)=\sum_{i=1}^{n} w_{i} R_{i}(x)+w_{0}
$$

Where $\mathrm{w}_{\mathrm{i}}$ - connection weight between the hidden neuron and output neuron, $\mathrm{w}_{0}$ is the bias, $\mathrm{x}$ is the input vector and $\mathrm{R}_{\mathrm{i}}$ is the radial basis function. Radial Basis Function Neural Networks comprises a single hidden layer of linearly independent functions $\left\{\Phi_{1}, \Phi_{2} \ldots \ldots . \Phi_{m}\right\}$ that forms a basis for an m-dimensional function space. A wide class of 
nonlinear mappings $f_{m}: R^{N} \rightarrow R$ belonging to so generated linear space, i.e. $f_{m} \in \operatorname{span}\left\{\Phi_{1}, \Phi_{2} \ldots \ldots . \Phi_{m}\right\}$, can be obtained by means of RBF network structure. Its transfer function is given by the following linear regression equation (3).

$$
f_{m}(x)=\sum_{k=1}^{m} w_{k} \Phi_{k}(x)+w_{0}
$$

Where $\Phi_{k}(x)=\Phi\left(\left\|x-c_{k}\right\| / s_{k}\right)$ are the basis functions (also termed the kernels) being translated dilations of a radially symmetric prototype function $\Phi: R_{N} \rightarrow R$ and $w_{k}$, $\mathrm{k}=0,1, \ldots \ldots ., \mathrm{m}$ are the adjustable weight coefficients of linear regression, $s_{k}$ is the dilation factor. Fig. 1 shows the schematic representation of RBFNN.

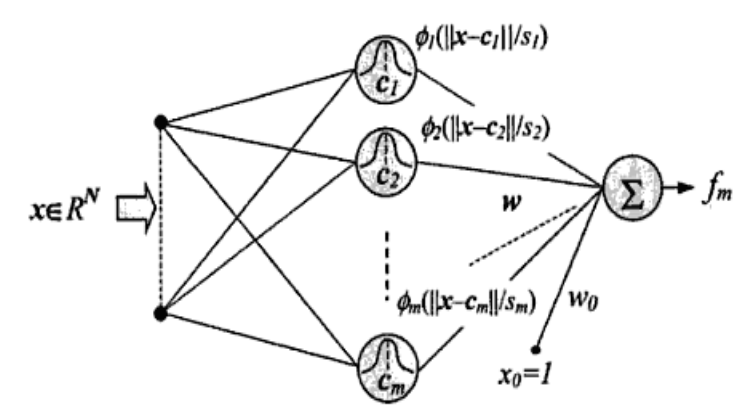

Fig. 1: Schematic representation of RBFNN (Source: https://chrisjmccormick.wordpress.com )

The various parameters used to estimate the performance of the models are the Root Mean Square Error (RMSE), Correlation Coefficient (r), Mean Absolute Error (MAE) and Standard Error of Estimate (SEE). The smaller the value of RMSE, MAE and SEE, the better will be the performance of the model. The Correlation Coefficient should be close to unity for better performance of the model.

\section{STUDY AREA}

Athiyannoor Block Panchayath located at South Western part of Trivandrum district that covers approximately $38 \mathrm{~km}^{2}$ is the study area as shown in Fig. 2, which is considered as over exploited due to the stage of ground water development and significant decline in water level (SGWB 2009). Later this block Panchayath categorised as semi critical (CGWB 2011). High concentration of water extracting structures (pumping wells) from the phreatic aquifer system is the root cause for the over exploitation of groundwater in Athiyannoor area. Different recharge facilities are provided in study area. Neyyar river is flowing through the study area and it flows near to the Thirupuram pumping well. Puvar canals are flowing nearer to Parachakkulam, Athiyannoor and Kollamkonam pumping wells. Vellayani lake flows nearer to Kadavinmoola pumping well. Puthalam pumping well is located at the hill foot so that it intercepts water from high elevations. In Karichal area, a radial collector well is provided for groundwater recharge. Venganoor pumping well is located in a sloping terrain. No any additional recharge facilities are provided in Kumili, Athiyannoor and Pulinkudi areas, so that recharge occurs in these areas from rainfall only. These are the hydrogeological features of the study area. Major formations include Warkalai formation, coastal alluvium, laterite and precambrian crystalline.

Ten pumping wells from the study area were considered for the analysis and all of them are operated by Kerala Water Authority. One observation well is considered near each pumping well.

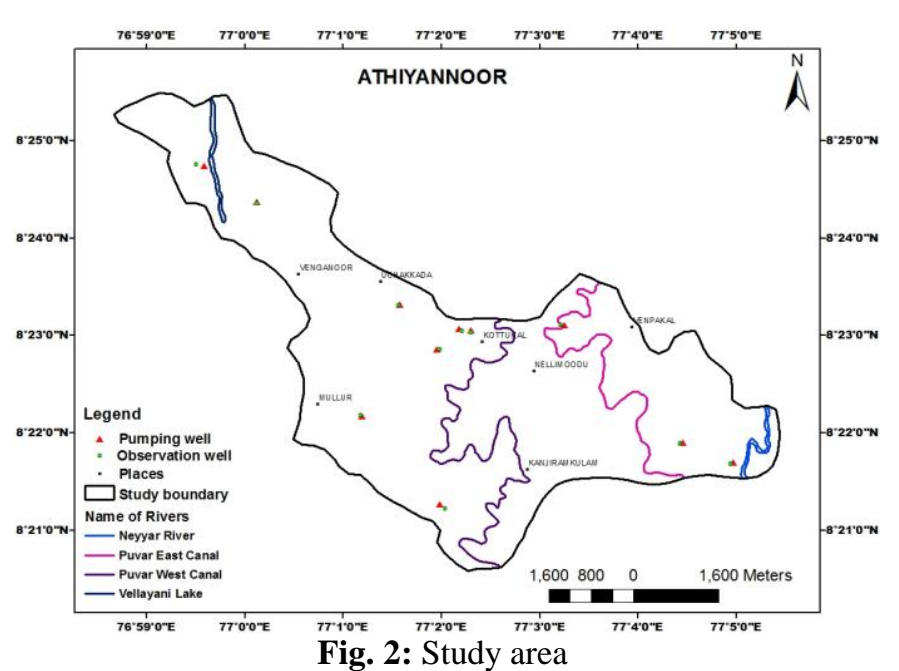

\section{DATA COLLECTION}

The pumping wells and their pumping rates collected from Kerala Water Authority are given in Table 1. Weekly groundwater level data were measured from all the 10 observation wells during January 2014 to March 2015 were used for modelling. The groundwater levels from January to December 2014 were used for simulation in MODFLOW and RBFNN. The groundwater levels from January to March 2015 were used for validation in MODFLOW and RBFNN. The rainfall and meteorological parameter values were collected from the site www.accuweather.com.

Table 1 Pumping wells and pumping rates (Source: Kerala Water Authority, 2013)

\begin{tabular}{|c|c|c|c|}
\hline $\begin{array}{l}\text { Sl. } \\
\text { No. }\end{array}$ & $\begin{array}{l}\text { Name of the } \\
\text { Pumping Well }\end{array}$ & $\begin{array}{l}\text { Observati } \\
\text { on well id }\end{array}$ & $\begin{array}{l}\text { Pumping } \\
\text { Rate } \\
(\mathrm{lpm})\end{array}$ \\
\hline 1 & $\begin{array}{l}\text { Parachakkulam } \\
\text { Pumping Well }\left(\mathrm{P}_{1}\right)\end{array}$ & $\mathrm{W}_{1}$ & 400 \\
\hline 2 & $\begin{array}{l}\text { Kollamkonam } \\
\text { Pumping Well }\left(\mathrm{P}_{2}\right)\end{array}$ & $\mathrm{W}_{2}$ & 700 \\
\hline 3 & $\begin{array}{l}\text { Athiyannoor } \\
\text { Pumping Well }\left(\mathrm{P}_{3}\right)\end{array}$ & $\mathrm{W}_{3}$ & 1500 \\
\hline 4 & $\begin{array}{l}\text { Puthalam Pumping } \\
\text { Well }\left(\mathrm{P}_{4}\right)\end{array}$ & $\mathrm{W}_{4}$ & 2500 \\
\hline 5 & $\begin{array}{ll}\text { Kumili } & \text { Pumping } \\
\text { Well }\left(\mathrm{P}_{5}\right) & \end{array}$ & $\mathrm{W}_{5}$ & 2500 \\
\hline 6 & $\begin{array}{l}\text { Thirupuram } \\
\text { pumping Well }\left(\mathrm{P}_{6}\right)\end{array}$ & $\mathrm{W}_{6}$ & 1700 \\
\hline 7 & $\begin{array}{ll}\text { Karichal } & \text { Pumping } \\
\text { Well }\left(\mathrm{P}_{7}\right) & \end{array}$ & $\mathrm{W}_{7}$ & 2800 \\
\hline
\end{tabular}




\begin{tabular}{|l|l|l|l|}
\cline { 2 - 3 } 8 & $\begin{array}{l}\text { Venganoor } \\
\text { Pumping Well }\left(\mathrm{P}_{8}\right)\end{array}$ & $\mathrm{W}_{8}$ & 1350 \\
\hline 9 & $\begin{array}{l}\text { Kadavinmoola } \\
\text { Pumping Well }\left(\mathrm{P}_{9}\right)\end{array}$ & $\mathrm{W}_{9}$ & 1600 \\
\hline 10 & $\begin{array}{l}\text { Pulinkudi Pumping } \\
\text { Well }\left(\mathrm{P}_{10}\right)\end{array}$ & $\mathrm{W}_{10}$ & 1100 \\
\hline
\end{tabular}

\section{RESULTS AND DISCUSSION}

The groundwater flow models were developed, simulated and predicted using numerical model MODFLOW and RBFNN. Predicted groundwater levels were validated with observed groundwater levels. Then a comparison is made with predicted values of groundwater levels using numerical model MODFLOW and RBFNN.

\subsection{Groundwater Flow Modelling using}

\section{MODFLOW}

The study area consists of an unconfined aquifer (Warkalai formation) for a depth of $30 \mathrm{~m}$. Since all the pumping wells and observation wells are within $30 \mathrm{~m}$ from ground surface, the study area was modelled as a single layer with thickness $30 \mathrm{~m}$. The study area was discretized in to $60 \mathrm{X} 60$ cells. The recharge values were estimated by Rainfall Infiltration Factor (RIF) method. For the Warkalai formation, RIF of 0.25 (Report of groundwater resource estimation committee, 2009) is taken, which is multiplied by total rainfall in order to get the recharge. Evapotranspiration values were computed using Penman's method. Pumping test was conducted at Kumili Pumping Well of the study area. Hydraulic conductivity of $27 \mathrm{~m} /$ day was obtained from Jacob's method. The outer boundary of study area was designated as no flow boundary. The river heads were properly assigned. Model was then calibrated under transient condition and simulations were done for one year at weekly time step. The calibration chart is shown in Fig. 3. It shows that NRMSE of $2.417 \%$ is obtained, which is less than $10 \%$. The calibrated value of hydraulic conductivity was found to be $7 \mathrm{~m} / \mathrm{day}$. The comparison of observed and predicted groundwater levels during simulation period in $\mathrm{W}_{1}$ and $\mathrm{W}_{5}$ are shown in figures 4 and 5. The performance of numerical model during simulation for 10 observation wells is given in Table 2 .

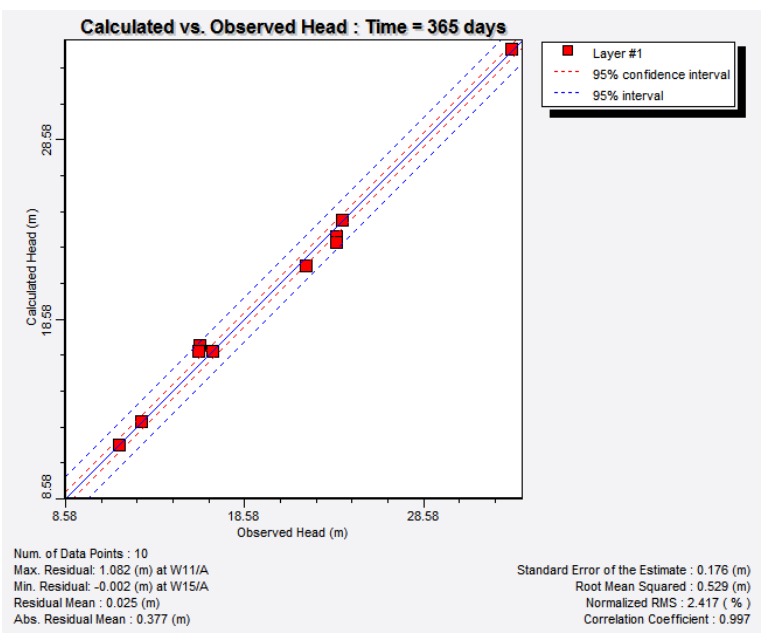

Fig. 3: Calibration chart of the model
Table 2: Performance of numerical model during simulation

\begin{tabular}{|l|l|l|l|l|}
\hline $\begin{array}{l}\text { Observation } \\
\text { Well id }\end{array}$ & RMSE & MAE & SEE & $\mathrm{r}$ \\
\hline $\mathrm{W}_{1}$ & 0.072 & 0.023 & 0.073 & 0.969 \\
\hline $\mathrm{W}_{2}$ & 0.255 & 0.014 & 0.258 & 0.899 \\
\hline $\mathrm{W}_{3}$ & 0.234 & 0.018 & 0.236 & 0.888 \\
\hline $\mathrm{W}_{4}$ & 0.845 & 0.647 & 0.853 & 0.843 \\
\hline $\mathrm{W}_{5}$ & 0.929 & 0.757 & 0.938 & 0.941 \\
\hline $\mathrm{W}_{6}$ & 0.823 & 0.284 & 0.831 & 0.802 \\
\hline $\mathrm{W}_{7}$ & 0.339 & -0.237 & 0.343 & 0.907 \\
\hline $\mathrm{W}_{8}$ & 0.386 & -0.102 & 0.390 & 0.895 \\
\hline $\mathrm{W}_{9}$ & 0.215 & 0.077 & 0.217 & 0.877 \\
\hline $\mathrm{W}_{10}$ & 0.297 & -0.154 & 0.300 & 0.732 \\
\hline
\end{tabular}

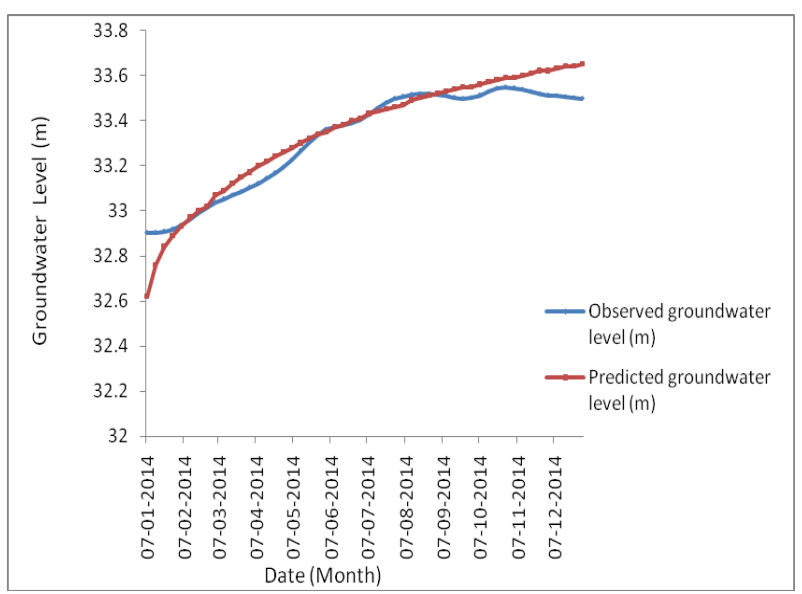

Fig. 4: Comparison of observed and predicted groundwater levels during simulation in $\mathrm{W}_{1}$

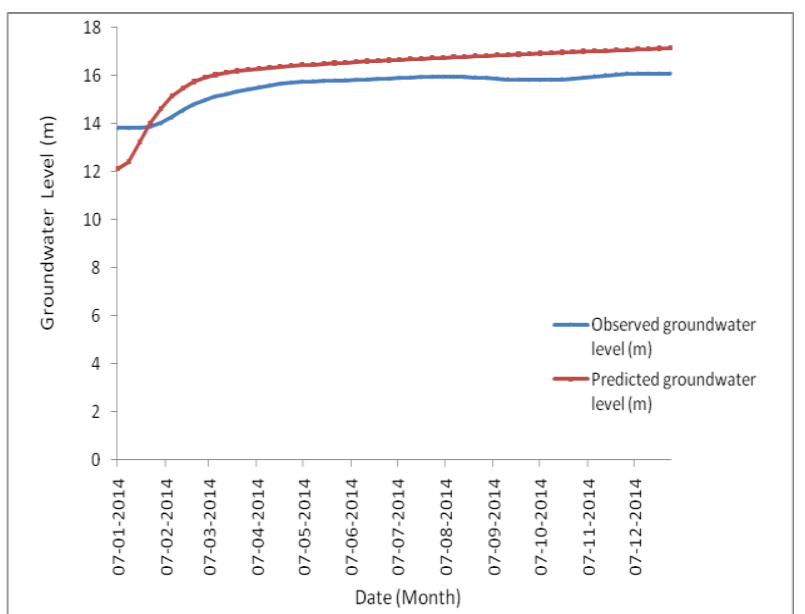

Fig. 5: Comparison of observed and predicted groundwater levels during simulation in $\mathrm{W}_{5}$

The performance of numerical model during validation is given in Table 3. The comparison of observed and predicted groundwater levels during validation in $\mathrm{W}_{1}$ and $\mathrm{W}_{5}$ are shown in figures 6 and 7. 
Table 3: Performance of numerical model during validation

\begin{tabular}{|l|l|l|l|l|}
\hline $\begin{array}{l}\text { Observation } \\
\text { Well id }\end{array}$ & RMSE & MAE & SEE & $\mathrm{r}$ \\
\hline $\mathrm{W}_{1}$ & 0.234 & 0.227 & 0.243 & 0.921 \\
\hline $\mathrm{W}_{2}$ & 0.446 & -0.432 & 0.464 & 0.831 \\
\hline $\mathrm{W}_{3}$ & 0.182 & 0.176 & 0.189 & 0.83 \\
\hline $\mathrm{W}_{4}$ & 0.135 & 0.124 & 0.141 & 0.77 \\
\hline $\mathrm{W}_{5}$ & 0.130 & 0.124 & 0.136 & 0.876 \\
\hline $\mathrm{W}_{6}$ & 0.135 & 0.112 & 0.140 & 0.776 \\
\hline $\mathrm{W}_{7}$ & 0.025 & -0.002 & 0.026 & 0.833 \\
\hline $\mathrm{W}_{8}$ & 0.134 & 0.094 & 0.139 & 0.839 \\
\hline $\mathrm{W}_{9}$ & 0.369 & 0.359 & 0.384 & 0.715 \\
\hline $\mathrm{W}_{10}$ & 0.073 & -0.058 & 0.076 & 0.819 \\
\hline
\end{tabular}

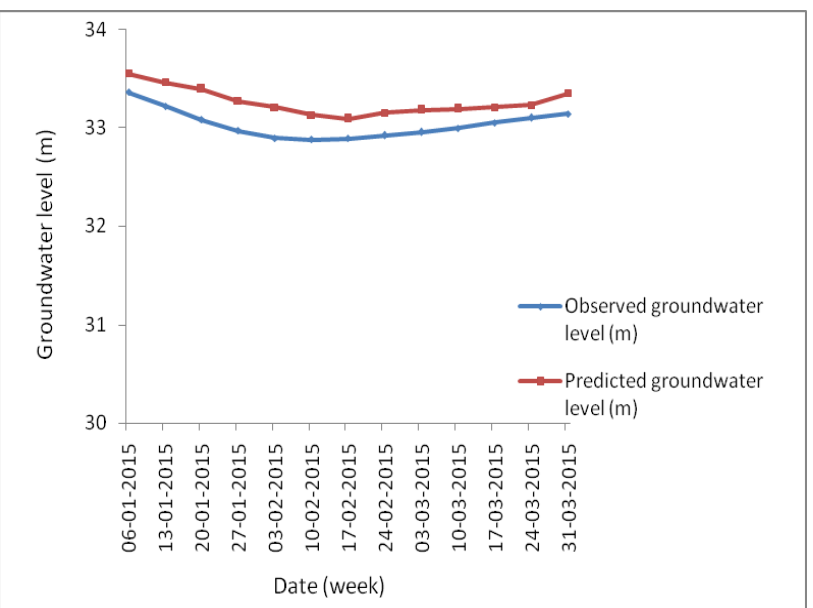

Fig. 6: Comparison of observed and predicted groundwater levels during validation in $\mathrm{W}_{1}$

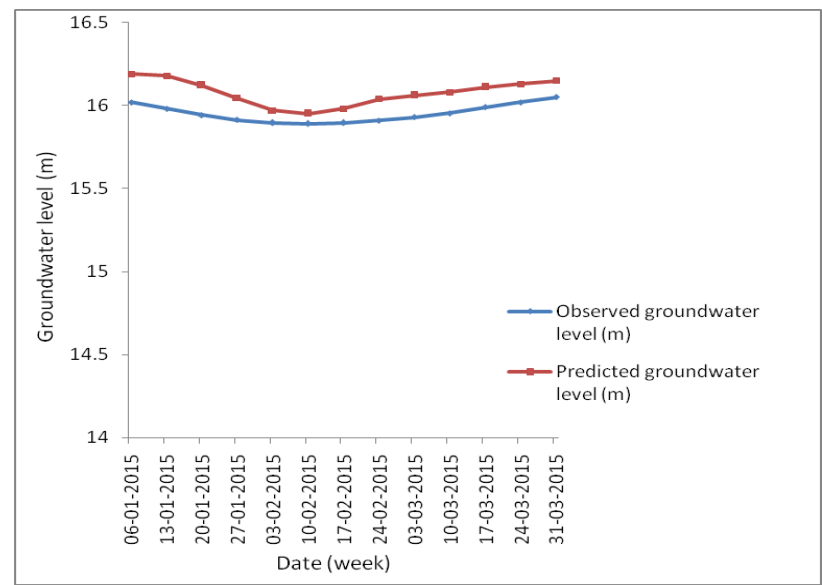

Fig. 7: Comparison of observed and predicted groundwater levles during validation in $\mathrm{W}_{5}$

The figures 6 and 7 revealed that predicted groundwater levels follows the same trend of observed groundwater levels. Thus numerical model using MODFLOW is good for weekly forecasting.

\subsection{Groundwater Level Forecasting using RBFNN}

A RBFNN model was developed for Athiyannoor Block Panchayath of Trivandrum district. The input parameters used for the study were recharge, evapotranspiration, pumping rate and groundwater level of previous time step.
The output was the groundwater level. Out of 65 weekly values of input and output parameters, 52 values were used for training and 13 values were used for testing. A MatLab program was used to develop the RBFNN model for the work. The neurons in the input layer were fixed as 4 and that of output layer was fixed as 1 . The network with the least RMSE was chosen as the best network. The best network was obtained by changing the number of neurons in the hidden layer and the spread (radius) of the function. The performance of RBFNN model during training process for the 10 observation wells in the study area is given in Table 4. A scatter plot of the observed and predicted groundwater levels during training for the observation wells $\mathrm{W}_{5}$ and $\mathrm{W}_{8}$ are shown in figures 8 and 9 .

Table 4: Performance of RBFNN model during training

\begin{tabular}{|l|l|l|l|l|}
\hline $\begin{array}{l}\text { Observation } \\
\text { Well id }\end{array}$ & RMSE & MAE & SEE & $\mathrm{r}$ \\
\hline $\mathrm{W}_{1}$ & 0.006 & 0.0001 & 0.006 & 0.9998 \\
\hline $\mathrm{W}_{2}$ & 0.021 & 0.0005 & 0.021 & 0.9966 \\
\hline $\mathrm{W}_{3}$ & 0.015 & $3.1 \mathrm{E}-11$ & 0.015 & 0.9984 \\
\hline $\mathrm{W}_{4}$ & 0.021 & $3.11 \mathrm{E}-11$ & 0.021 & 0.9968 \\
\hline $\mathrm{W}_{5}$ & 0.003 & $5.38 \mathrm{E}-05$ & 0.003 & 0.9999 \\
\hline $\mathrm{W}_{6}$ & 0.009 & -0.0003 & 0.009 & 0.9995 \\
\hline $\mathrm{W}_{7}$ & 0.007 & $5.26 \mathrm{E}-05$ & 0.007 & 0.9998 \\
\hline $\mathrm{W}_{8}$ & 0.009 & $-2.734 \mathrm{E}-05$ & 0.009 & 0.9995 \\
\hline $\mathrm{W}_{9}$ & 0.033 & $1.19 \mathrm{E}-11$ & 0.033 & 0.9907 \\
\hline $\mathrm{W}_{10}$ & 0.015 & 0.0001 & 0.015 & 0.9985 \\
\hline
\end{tabular}

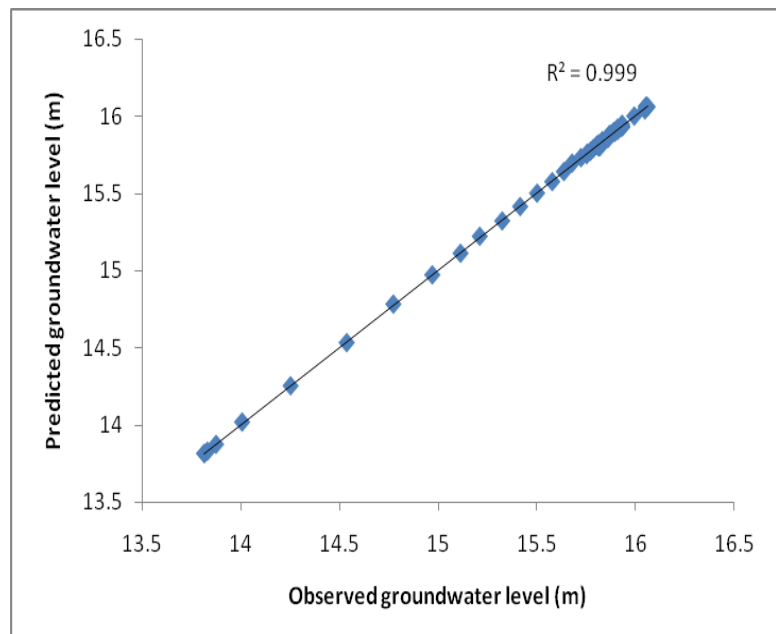

Fig. 8: Scatter plot of observed and predicted groundwater levels during training in $\mathrm{W}_{5}$ 


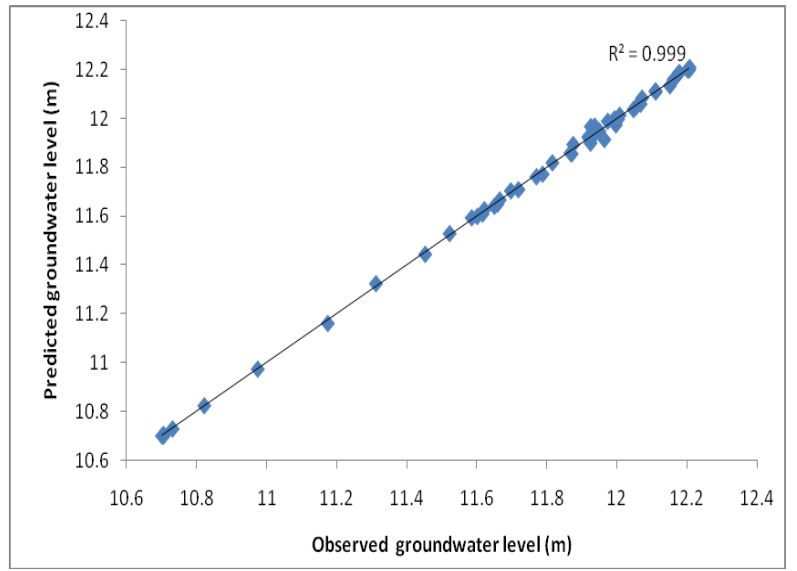

Fig. 9: Scatter plot of observed and predicted groundwater levels during training in $\mathrm{W}_{8}$

Very high correlation coefficient and low RMSE is obtained for all the observation wells during training. The performance of RBFNN model during training is superior compared to the simulation in numerical model using MODFLOW. Using the best network, testing was carried out and the performance of RBFNN model during testing is given in Table 5. The comparison of observed and predicted groundwater levels during testing in $\mathrm{W}_{5}$ and $\mathrm{W}_{8}$ are shown in figures 10 and 11.

Table 5: Performance of RBFNN model during testing

\begin{tabular}{|l|l|l|l|l|}
\hline $\begin{array}{l}\text { Observation } \\
\text { Well id }\end{array}$ & RMSE & MAE & SEE & $\mathrm{r}$ \\
\hline $\mathrm{W}_{1}$ & 0.0634 & 0.0190 & 0.0660 & 0.9390 \\
\hline $\mathrm{W}_{2}$ & 0.0846 & -0.0421 & 0.0881 & 0.9510 \\
\hline $\mathrm{W}_{3}$ & 0.0332 & 0.0067 & 0.0346 & 0.9560 \\
\hline $\mathrm{W}_{4}$ & 0.0184 & 0.0096 & 0.0191 & 0.9150 \\
\hline $\mathrm{W}_{5}$ & 0.0212 & 0.0035 & 0.0221 & 0.9810 \\
\hline $\mathrm{W}_{6}$ & 0.0558 & 0.0419 & 0.0580 & 0.9610 \\
\hline $\mathrm{W}_{7}$ & 0.0148 & -0.0006 & 0.0154 & 0.9520 \\
\hline $\mathrm{W}_{8}$ & 0.0579 & 0.0405 & 0.0603 & 0.9770 \\
\hline $\mathrm{W}_{9}$ & 0.0368 & -0.0066 & 0.0383 & 0.9110 \\
\hline $\mathrm{W}_{10}$ & 0.0203 & -0.0015 & 0.0211 & 0.9600 \\
\hline
\end{tabular}

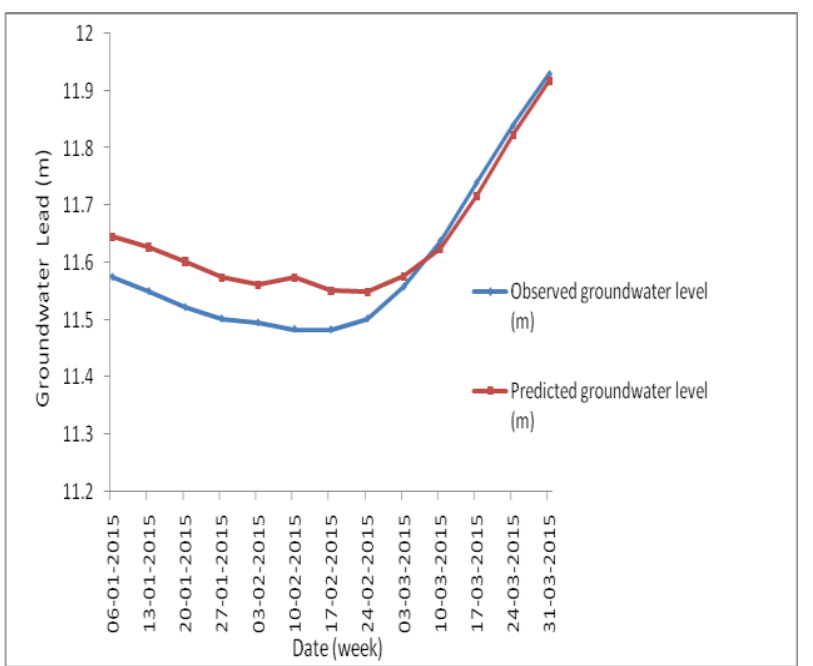

Fig. 10: Comparison of observed and predicted groundwater levels during testing in $\mathrm{W}_{5}$

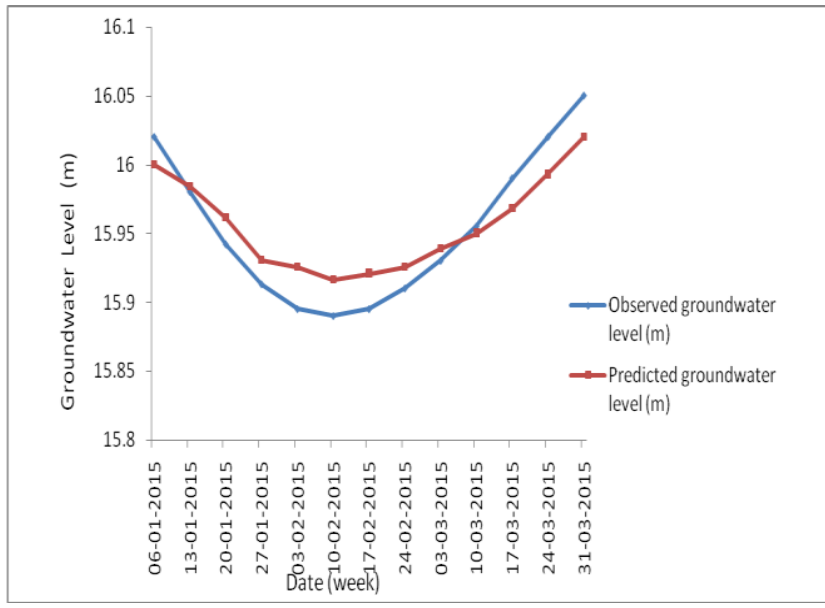

Fig. 11: Comparison of observed and predicted groundwater levels during testing in $\mathrm{W}_{8}$

Figures 10 and 11, reveals that the observed and predicted groundwater levels follows the same trend and at fig. 10, the predictions are very close to observed values of groundwater levels during the month of March due to the effect of rainfall. The performance characteristics of both models indicate that RBFNN model is better than numerical model using MODFLOW for weekly groundwater level forecasting. This is due to high correlation coefficients obtained during training and testing of RBFNN model. During the training process in RBFNN, all the observation wells had shown a high correlation coefficient of 0.999. But during simulation in MODFLOW, even though all the observation wells had shown good correlation coefficients, they were all less than that obtained from RBFNN. The numerical model MODFLOW had given good simulations for $\mathrm{W}_{1}$ which is located at an elevated area and also for $\mathrm{W}_{5}$ and $\mathrm{W}_{8}$. During validation, RBFNN had given high correlation coefficients for all the observation wells than numerical model using MODFLOW. A high correlation coefficient of 0.981 is obtained for $\mathrm{W}_{5}$ and 0.976 for $\mathrm{W}_{8}$ during validation of RBFNN model. A high correlation coefficient of 0.921 and 0.876 were obtained for $\mathrm{W}_{1}$ and $\mathrm{W}_{5}$ during validation in MODFLOW. But good match is obtained for the predictions at $\mathrm{W}_{1}$ in MODFLOW as well as RBFNN.

\section{SUMMARY}

A groundwater flow model for Athiyannoor Block Panchayath was developed using numerical model MODFLOW 2000 and RBFNN. The groundwater levels were simulated, predicted and validated. These predicted groundwater levels from both models were compared. The performance parameters used in the two models shows that RBFNN model is better than numerical model using MODFLOW for weekly groundwater level forecasting.

\section{RECOMMENDATIONS AND CONCLUSION}

A groundwater flow model for Athiyannoor Block Panchayath, Trivandrum district was developed using numerical model MODFLOW and RBFNN. Both the models had given good simulation and prediction results and can be used effectively for weekly groundwater level forecasting. 
The comparison of these two types of models revealed that the RBFNN is better than MODFLOW for short range (weekly) groundwater level forecasting. RBFNN models doesn't require the characterization of physical properties of the study area, thus requires less number of inputs which make the modelling easy. But in MODFLOW, detailed description of hydrogeology, aquifer parameters, boundary conditions and river stage are necessary, thus requires large number of inputs which make the modelling tedious. However, numerical model using MODFLOW gives total water balance of the system since input output relationship is given by groundwater flow equation. But RBFNN model is blackbox in nature since the input output relationship is unknown. The changes in the input or output parameters can be easily incorporated to existing numerical models, but total modelling from beginning is necessery for RBFNN under such conditions. The spatial variations of different inputs can be well simulated in numerical model and it is not possible in RBFNN. The groundwater level at the previous time step is also included as an input parameter in RBFNN which can accommodate spatial variation of different hydrogeological factors in the study area. Thus numerical model using MODFLOW and empirical model RBFNN can be effectively used for groundwater level forecasting. The type of groundwater flow model for a particular application can be selected based on the advantages offerred by numerical and empirical models.

\section{REFERENCES}

[1] Bezhad, M., Asghari, K., and Coppola Jr., E., (2010). "Comparative Study of SVMs and ANNs in Aquifer Water Level Prediction." Journal of Computing in Civil Engineering., ASCE, 24(5), 408-413.

[2] Central Groundwater Board (2009). "Report of the Ground water resource estimation Committee", pp 17.

[3] Central Groundwater Board (2011). "Dynamic groundwater resources of India”. pp. 127.

[4] Chang Xu., Hui Jia., Rong Wang., Hao Wu., (2013). "Groundwater Level Prediction Based on BP and RBF Neural Network". International Journal of Applied Sciences and Engineering Research., Research Article, 2 (3), 263-269.

[5] Coppola, E., Szidarovszky, F., Poulton, M., Charles, E., (2003). "Artificial neural network approach for predicting transient water levels in a multilayered groundwater system under variable state, pumping, and climate conditions". J. Hydrologic Engineering., ASCE, 8 (6), 348-360.

[6] https://chrisjmccormick.wordpress.com

[7] https://www.accuwether.com

[8] Kerala Water Authority, Unpublished technical report

[9] Mohanty, S., Madan, K. Jha., Kumar, A., and Panda, D.K., (2013). "Comparative evaluation of numerical model and artificial neural network for simulating groundwater flow in Kathajodi-Surua Inter-basin of Odisha, India." Journal of Hydrology., Elsevier, 495(2013), 38-51.

[10] Kresic, N., (1996). "Quantitative Solutions in Hydrogeology and Groundwater Modelling”. LAW
Engineering and Environmental Services, INC., LEWIS Publishers, New York.

[11] State Groundwater Board, Dynamic Ground Water Resources of Kerala (As on March 31, 2009) pp. 29.

[12] Varalakshmi, V., Venkateswara Rao, B., SuriNaidu, L., and Tejaswini, M., (2012). "Groundwater Flow Modelling of a Hard Rock Aquifer: Case Study." Journal of Hydrologic Engineering., ASCE, 19 (5), 877-886. 